\title{
Educational interventions used to improve the cognitive and social development of children and adolescents with autism
}

\author{
Intervenções educacionais utilizadas para melhoria do desenvolvimento cognitivo e social de \\ crianças e adolescentes com autismo \\ Intervenciones educativas utilizadas para mejorar el desarrollo cognitivo y social de niños y
} adolescentes con autismo

Received: 07/06/2021 | Reviewed: 07/13/2021 | Accept: 07/16/2021 | Published: 07/25/2021

Karine Alonso dos Santos

ORCID: https://orcid.org/0000-0001-7156-6069 Universidade José do Rosário Vellano, Brazil E-mail: karine.santos@aluno.unifenas.br

Igor de Oliveira Freire Monteiro

ORCID: https://orcid.org/0000-0002-2480-2927 Universidade José do Rosário Vellano, Brazil E-mail: igor.monteiro@ aluno.unifenas.br

Gabriely Coêlho Dos Santos

ORCID: https://orcid.org/0000-0001-7156-6069 Universidade José do Rosário Vellano, Brazil

E-mail: gabriely.santos@ aluno.unifenas.br

Ian Schröder Anjos

ORCID: https://orcid.org/0000-0002-5884-7621 Universidade José do Rosário Vellano, Brazil

E-mail: ian.anjos@aluno.unifenas.br

Annita Maria De Oliveira Fagundes ORCID: https://orcid.org/0000-0002-7142-2257

Universidade José do Rosário Vellano, Brazil E-mail: annita.fagundes@aluno.unifenas.br

Sérgio Antônio Murad Neto

ORCID: https://orcid.org/0000-0001-8490-6050 Universidade José do Rosário Vellano, Brazil E-mail: Sergio.neto@aluno.unifenas.br

Gabriel Henrique Ferracioli Alvarenga ORCID: https://orcid.org/0000-0002-4131-9320 Universidade José do Rosário Vellano, Brazil E-mail: Gabriel.alvarenga@ @aluno.unifenas.br

Simone Caetani Machado ORCID: https://orcid.org/0000-0002-3440-7162 Universidade José do Rosário Vellano, Brazil E-mail: simone.machado@unifenas.br

Danielly Beraldo dos Santos Silva ORCID: https://orcid.org/0000-0002-3144-7476 Universidade José do Rosário Vellano, Brazil E-mail: danielly.silva@prof.unifenas.br

\begin{abstract}
Difficulty in communication and socialization are the main characteristics presented by individuals diagnosed with autism. For children and adolescents with autism to have a better inclusion and understanding of the contents covered in the classroom, several methodologies have been developed and used that include active ASD teaching and learning strategies. Therefore, this study aimed to carry out a systematic review to verify which educational interventions have been used to improve the cognitive and social development of children and adolescents diagnosed with autism. For this reason, a search for scientific articles published between the years 2015 and 2020 was carried out in the Scielo, PubMed, Lilacs, Bireme, and Medline databases. The research included only studies that aimed at social and educational interventions for children and adolescents ( 2 to 18 years old) with autism. In the bibliographic survey, 227 articles were found. From the application of inclusion and exclusion criteria, 16 articles were evaluated in this systematic review. The studies addressed educational strategies that explored various aspects related to vision, hearing, smell, language, and sociability. The use of technological resources (applications, virtual games, video modeling, and robots) stimulated the cognitive and social development of the evaluated population. The results
\end{abstract}


presented were favorable for the increase, mainly, in the frequency of non-verbal initiatives and the use of eye contact in responses to communication partners.

Keywords: Special education; Inclusion; Socialization; ASD.

\section{Resumo}

A dificuldade de comunicação e socialização são as principais características apresentadas por indivíduos diagnosticados com o autismo. Para que crianças e adolescentes com autismo tenham uma melhor inclusão e compreensão dos conteúdos abordados em sala de aula, têm-se desenvolvido e utilizado diversas metodologias que incluem estratégias ativas de ensino e aprendizagem. Portanto, o objetivo deste estudo foi realizar uma revisão sistemática para verificar quais as intervenções educacionais que têm sido usadas para melhoria do desenvolvimento cognitivo e social de crianças e adolescentes diagnosticadas com autismo. Para tanto, foi realizado a busca de artigos científicos publicados entre os anos 2015 e 2020, nas bases de dados SciELO, PubMED, LILACS, Bireme e MEDLINE. Na pesquisa foram incluídos apenas os estudos que visavam intervenções sociais e educacionais para crianças e adolescentes ( 2 a 18 anos) com autismo. No levantamento bibliográfico, 227 artigos foram encontrados. A partir da aplicação de critérios de inclusão e exclusão, 16 artigos foram avaliados nesta revisão sistemática. Os estudos abordaram estratégias educacionais que exploraram vários aspectos relacionados à visão, audição, olfato, linguagem e sociabilidade. O uso de recursos tecnológicos (aplicativos, jogos virtuais, modelagem de vídeo e robôs) estimulou o desenvolvimento cognitivo e social da população avaliada. Os resultados apresentados foram favoráveis para o aumento, principalmente, na frequência de iniciativas não verbais e o uso do contato visual em respostas aos parceiros de comunicação. A inserção de diversos modelos educativos associadas às brincadeiras lúdicas e ao uso de recursos tecnológico podem acarretar em resultados satisfatórios acerca do desenvolvimento de habilidades, alfabetização e interações sociais em crianças e adolescentes autistas.

Palavras-chave: Educação especial; Inclusão; Socialização; TEA.

\section{Resumen}

La dificultad en la comunicación y socialización son las principales características que presentan las personas diagnosticadas con autismo. Para que los niños y adolescentes con autismo tengan una mejor inclusión y comprensión de los contenidos cubiertos en el aula, se han desarrollado y utilizado diversas metodologías que incluyen estrategias activas de enseñanza y aprendizaje. El objetivo de este estudio fue realizar una revisión sistemática para verificar qué intervenciones educativas se han utilizado para mejorar el desarrollo cognitivo y social de niños y adolescentes diagnosticados con autismo. Por ello, se realizó una búsqueda de artículos científicos publicados entre los años 2015 y 2020 en las bases de datos SciELO, PubMED, LILACS, Bireme y MEDLINE. La investigación incluyó solo estudios que tenían como objetivo intervenciones sociales y educativas para niños y adolescentes (de 2 a 18 años) con autismo. En el relevamiento bibliográfico se encontraron 227 artículos. A partir de la aplicación de los criterios de inclusión y exclusión, se evaluaron 16 artículos en esta revisión sistemática. Los estudios abordaron estrategias educativas que exploraron diversos aspectos relacionados con la visión, el oído, el olfato, el lenguaje y la sociabilidad. El uso de recursos tecnológicos (aplicaciones, juegos virtuales, modelado de video y robots) estimuló el desarrollo cognitivo y social de la población evaluada. Los resultados presentados fueron favorables para el incremento, principalmente, en la frecuencia de iniciativas no verbales y el uso del contacto visual en las respuestas a los interlocutores. La inclusión de diferentes modelos educativos asociados a los juegos lúdicos y el uso de recursos tecnológicos puede conducir a resultados satisfactorios en cuanto al desarrollo de habilidades, alfabetización e interacciones sociales en niños y adolescentes autistas.

Palabras clave: Educación especial; Inclusión; Socialización; TEA.

\section{Introduction}

The term psychiatric or mental disorder is used to characterize people who suffer from conditions of abnormality or impairment of a psychological, mental, or cognitive nature (Dos Santos et al., 2020). According to the Brazilian Psychiatric Association (ABP, 2021), mental disorders are the second most frequent reason for emergency care, representing a challenge for health systems, particularly in low-developed countries.

Autism Spectrum Disorder (ASD), considered one of the psychiatric or mental disorders, is characterized by an early onset neurological development disorder, impairment of social and communication skills. ASD covers autistic disorder (autism), Rett syndrome, Asperger's disorder, childhood disintegrative disorder, and pervasive developmental disorder not otherwise specified (Monteiro et al., 2020). ASD has a multifactorial cause, that is, genetic and environmental factors are involved. Eshraghi et al. (2018) and Frye et al. (2019) showed that alterations in molecular and biochemical biomarkers, as well as epigenetic alterations, can trigger ASD. 
Individuals with autism may exhibit hyperactivity, impulsivity, aggressive behaviors, peculiar sensory and perceptual responses (exaggerated fear of harmless stimuli or fascination with visual stimuli, sleep and gastrointestinal disturbances, and epilepsy) (DSM-IV-TR, APA 2000; Frye et al. al., 2019). In the case of children with autistic disorder, the main characteristics are repulsion in interpersonal relationships, acquisition delays, speech development disorders, motor difficulties, repetitive and stereotyped behaviors. Studies show that in the early stages of life, children and adolescents with ASD have a lower quality of life than children and adolescents with normal development (Kuhlthau et al., 2010; Arias et al., 2018).

In 2001, the National Research Council of the National Academies defined education for individuals with ASD as promoting the acquisition of skills or knowledge, including socialization; adaptive skills; language and communication; academic learning, and reduction of challenging behaviors, to increase functional independence, improve quality of life and alleviate family stress (Sengupta et al. 2015). In 2014, people with ASD gained legal support in terms of access to various services to which they are fully entitled. Law 12,764/2012 was regulated by Presidential Decree 8,368/2014 and guaranteed the qualification and accessibility to public services of the Unified Health System (SUS), education, and social protection for people with ASD.

Even after the implementation of Law 12,764/2012, efforts by schools and institutions, Biggs and Carter (2016) showed that family perceptions (classifications) about the quality of life of sons and daughters with autism were significantly lower than the rankings from a normative sample of young people of similar ages in the areas of social and educational support; physical and psychological well-being. In the educational sphere, individuals with ASD are disadvantaged by the educational system from the beginning of life (Jury et al. 2021).

For individuals with autism to have a better inclusion and understanding of the content covered in the classroom, institutions, and schools use several behavioral, developmental, and visual strategies. Behavioral strategies promote the learning of new behaviors. Educators/instructors promote and repeat such behavior until the child with autism successfully acquires it (Buemo et al., 2019).

A developmental strategy is a child-only approach. Thus, it uses materials and activities that are related to its development, for example, toys, games, among others. According to the interest on the part of students with ASD for these materials, the educator can direct ASD teaching towards verbal or manual strategies, focusing mainly on perception, communication, and language. The visual strategy can include the use of image and environmental enrichment (chairs, cubicles, boxes, landscape, among others). This strategy is focused on developing independence as well as skills, which facilitate group activities (Sengupta et al. 2015).

The improvement of the quality of life, such as the social and educational inclusion of the autistic person, helps in their development. However, the social and educational inclusion of autistic people is still a problem for society as a whole, as shown above. Based on this information, this study aimed to carry out a systematic review to verify which educational interventions have been used to improve the cognitive and social development of children and adolescents diagnosed with autism.

\section{Methodology}

This study is a systematic literature review developed following the guidelines of the Preferred Reporting Items for Systematic Reviews and Meta-Analyses (PRISMA) (Page et al., 2021). The studies were selected according to these criteria: population, interventions, comparators, outcome(s) of interest, and study design (PICO), as described in Table 1. The selected studies were cohort, randomized clinical trials, controlled studies before and after, retrospective comparative studies, and prospective comparative studies. 
Table 1. Description of the PICO (population, interventions, comparators, outcomes) strategy.

\begin{tabular}{ll}
\hline Definition & Description \\
\hline patients & Children and adolescents aged 2 to 18 years with autism spectrum disorder \\
Intervention & Social and/or educational inclusion \\
Comparison & No social inclusion \\
Outcomes & Improvements in the patient's behavioral symptoms \\
\hline
\end{tabular}

Source: Authors.

The searches were performed from April 1st to 26th, 2021. The following search terms were used: "Autistic Spectrum Disorder", “Intervention" "Strategies", “Interpersonal Relations", "Behavioral Syndrome”, "Inclusive Education”, “Child”, and "Autism". These terms were selected from the Health Science Descriptors (DeCS) and used in a randomized manner (AND/OR). The literature search was conducted through the following databases: SciELO, PubMed, LILACS, Bireme, and MEDLINE. As inclusion criteria, the following were established: 1) original studies with a population aged 2 to 18 years with autism; 2) studies aimed at providing specialized educational care for people with autism; 3) studies aimed at social and educational interventions for people with autism; 4) original research that provided sufficient detail about methods and results, allowing the identification and aggregation of data and results; 5) studies published between 2015 and 2020 in English.

The exclusion criteria were: 1) research that investigated educational interventions and social inclusion in people over 18 years of age with autism. 2) studies that were published in case report formats; scientific abstracts; academic posters; narrative, integrative or systematic literature review; dissertations, and theses. The studies found were sent to a bibliographic reference manager and duplicates were removed.

In the first step, two authors (ALS and DBSS) evaluated the title and abstract to verify the inclusion and exclusion criteria. The selected studies were evaluated by three other authors (ALS, IOFM, and SAMN), through the full reading of the text. The articles returned based on the selected criteria were analyzed for quality using the methodology of PEDro scales, based on the Delphi list (Beaton, et al., 2002). Data extracted from selected studies were: Country/place where the study was conducted; study design; the age of the population studied; description of the intervention and duration; assessment tools and outcome measures.

\section{Results}

Through the search process about the scientific productions extracted through the databases, 227 articles were found. Considering the screening and eligibility through inclusion and exclusion descriptions, 16 articles were selected to structure the body of this systematic study, which represented an approximate percentage of $7.05 \%$ of the initial survey (Figure 1). Tables 2 and 3 show the general characteristics, interventions performed, and results obtained from all studies included in this systematic review. 
Figure 1. PRISMA Flow Diagram (Page et al., 2021) of the steps related to the selection process of articles included in the systematic review, according to the inclusion and exclusion criteria applied.

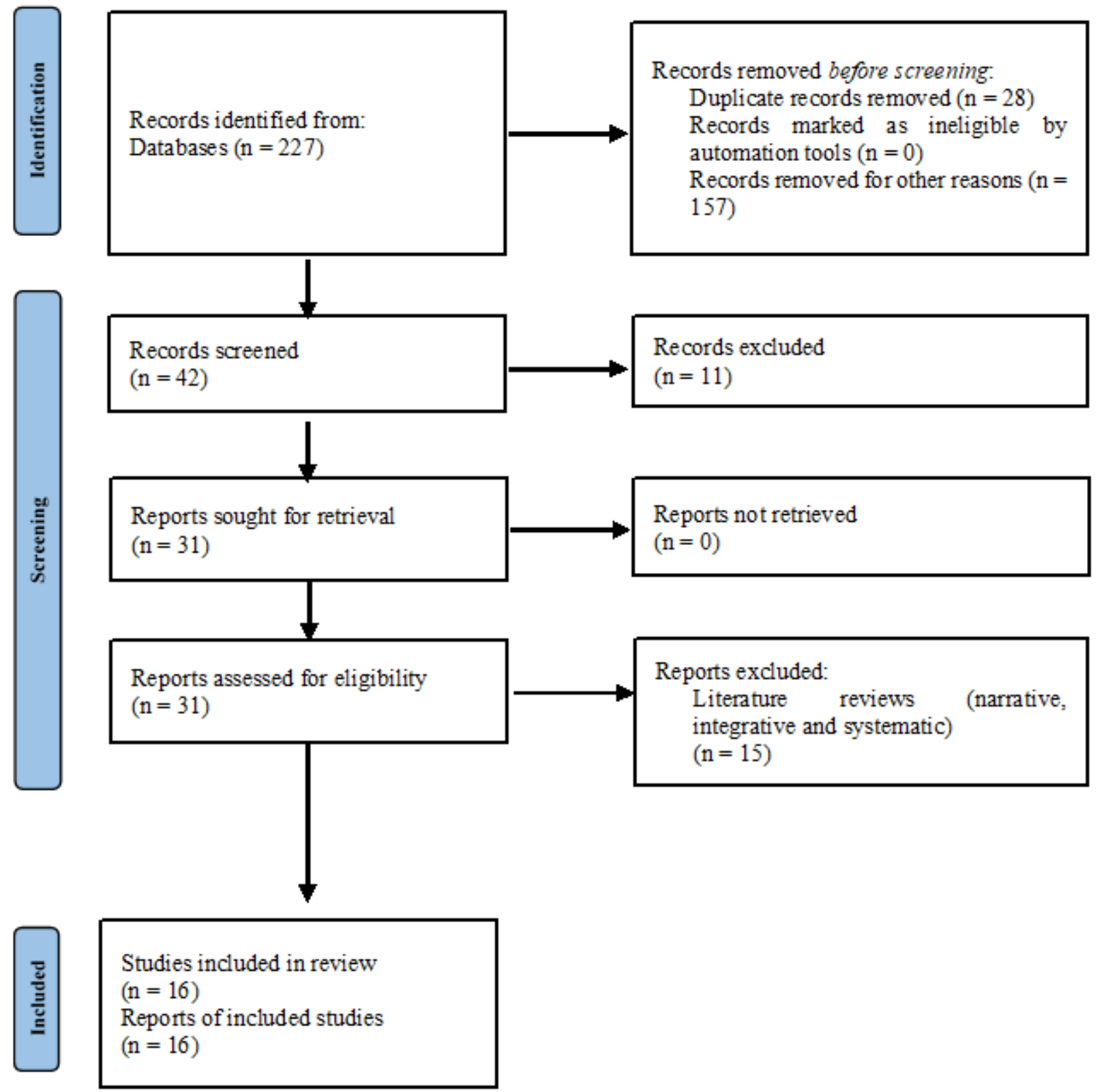

Source: Authors. 
Table 2. General characteristics (country, experimental design, sample size, age, and duration of intervention) of all studies included in this systematic review.

\begin{tabular}{|c|c|c|c|c|c|}
\hline Paper & Country/Location & $\begin{array}{l}\text { Type of study and//or experimental } \\
\text { design }\end{array}$ & $\begin{array}{l}\text { sample } \\
\text { size }\end{array}$ & $\begin{array}{l}\text { Age of the studied } \\
\text { population }\end{array}$ & $\begin{array}{l}\text { Duration of } \\
\text { intervention }\end{array}$ \\
\hline $\begin{array}{l}\text { Saint-Georges et al, } \\
2020\end{array}$ & France & $\begin{array}{l}\text { Randomized, blinded, multicenter, and } \\
\text { controlled clinical trial }\end{array}$ & 72 & 5 to 9 years & 36 months \\
\hline Lee et al, 2020 & China & A single case involving multiple probes & 3 & 4 to 5 years & Data not presented \\
\hline Dueñas et al, 2019 & US & multiple polls & 3 & 4 years & Data not presented \\
\hline $\begin{array}{l}\text { Thirumanickam, et al, } \\
2018\end{array}$ & Australia & alternate treatments and multiple baselines & 4 & 11 to 18 years old & Data not presented \\
\hline Caron, et al., 2018 & US & A single case involving multiple probes & 5 & 6 to 14 years old & Data not presented \\
\hline Mandak et al, 2019 & US & A single case involving multiple probes & 3 & 3 to 5 years & Data not presented \\
\hline Westeryeld et al., 2017 & Australia & Data not presented & 57 & 4 to 6 years & Data not presented \\
\hline Sam et al, 2020 & US & Data not presented & 486 & 8 years (average) & 1 school year \\
\hline Locke et al, 2016 & US & Baseline & 102 & 5 to 12 years & Data not presented \\
\hline Fantasia et al, 2020 & Italy & Data not presented & 29 & 6 to 12 years & Data not presented \\
\hline Plavinick et al, 2015 & US & Single Case Reversal Project & 3 & 5 to 6 years & Data not presented \\
\hline Dass et al, 2018 & US & Data not presented & 3 & 5 to 6 years & Data not presented \\
\hline Yun et al, 2017 & South Korea & Randomized Control Study & 15 & 4 and 7 years & Data not presented \\
\hline $\begin{array}{l}\text { Kostrubieck; Kruck, } \\
2020\end{array}$ & France & collaborative study & 20 & 5 to 10 years & 6 months \\
\hline
\end{tabular}


Table 3. General characteristics (evaluation tool, description, and main intervention results) of the studies included in this systematic review.

\begin{tabular}{|c|c|c|c|}
\hline Paper & Assessment tool & Description of the intervention & Outcomes \\
\hline Leão et al., 2019 & $\begin{array}{l}\text { Semi-structured interview with } \\
\text { parents and ASDchers; protocol } \\
\text { for observing the frequency and } \\
\text { quality of communicative acts; } \\
\text { social validity questionnaire; } \\
\text { intervention fidelity protocol }\end{array}$ & $\begin{array}{l}\text { Intervention based on self- } \\
\text { regulation of learning in the context } \\
\text { of specialized educational care }\end{array}$ & $\begin{array}{l}\text { Increased frequency of non-verbal } \\
\text { initiatives and the use of eye } \\
\text { contact in communication } \\
\text { responses. }\end{array}$ \\
\hline Saint-Georges et al., 2020 & $\begin{array}{l}\text { Psychoeducational Profile (PEP- } \\
\text { 3); Child Autism Rating Scale } \\
\text { (CARS); interview-revised } \\
\text { diagnostic autism (ADI-R); } \\
\text { vineland adaptive behavior Scale- } \\
\text { II (VABS-II); children's global } \\
\text { assessment scale (CGAS) and } \\
\text { annual educational performance. }\end{array}$ & $\begin{array}{l}\text { Encouragement of spontaneous } \\
\text { communication, promoting skills } \\
\text { through play with peers, supporting } \\
\text { positive behaviors. }\end{array}$ & $\begin{array}{l}\text { Improvement in school skills. } \\
\text { Children included in the study } \\
\text { were more likely to be placed in } \\
\text { regular classrooms than children } \\
\text { who received only usual care. } \\
\text { Generalization for clinical } \\
\text { variables such as communication } \\
\text { or social skills was not achieved. }\end{array}$ \\
\hline Lee et al., 2020 & $\begin{array}{l}\text { Application of standardized tests; } \\
\text { assessment of verbal behavior } \\
\text { milestones and placement } \\
\text { program (VB-MAPP); Wechsler } \\
\text { intelligence scale for children } \\
\text { (WISC-IV); Child Autism Rating } \\
\text { Scale (CARS); Developmental } \\
\text { Behavior Assessment for } \\
\text { Children with Autism (DBACA) } \\
\text { and Parent Questionnaire }\end{array}$ & $\begin{array}{l}\text { Development of a playful activity } \\
\text { involving the application of } \\
\text { instructions and objectives for each } \\
\text { theme, encouraging the correct } \\
\text { response of the child during the } \\
\text { execution of these activities and } \\
\text { with the help of the instructor. }\end{array}$ & $\begin{array}{l}\text { The practice of activities } \\
\text { involving the replacement of } \\
\text { objects made it possible to } \\
\text { increase the incidence of children } \\
\text { developing playful games, } \\
\text { culminating in the expansion of } \\
\text { playful behavior. }\end{array}$ \\
\hline Dueñas et al., 2019 & $\begin{array}{l}\text { Assessment of verbal behavior } \\
\text { milestones and placement } \\
\text { program (VB-MAPP); }\end{array}$ & $\begin{array}{l}\text { Intervention based on the } \\
\text { application of a video model and the } \\
\text { application of a "make-believe" } \\
\text { game, seeking to stimulate the } \\
\text { children's verbalization. }\end{array}$ & $\begin{array}{l}\text { Considerable improvement in } \\
\text { expression exposure through } \\
\text { words during play with typically } \\
\text { developing peers in the early } \\
\text { childhood environment. }\end{array}$ \\
\hline Stone et al., 2018 & $\begin{array}{l}\text { Semi-structure interviews; } \\
\text { observation of screens recorded } \\
\text { from the multidisciplinary game } \\
\text { called Minecraft }\end{array}$ & $\begin{array}{l}\text { Intervention based on the analysis of } \\
\text { behavior during a multiplayer game. }\end{array}$ & $\begin{array}{l}\text { Increase and maintenance of } \\
\text { social interaction both in the } \\
\text { virtual and physical environment. }\end{array}$ \\
\hline $\begin{array}{l}\text { Thirumanickam, et al., } \\
2018\end{array}$ & $\begin{array}{l}\text { Application of the Peabody } \\
\text { Image Vocabulary Test (PPVT- } \\
\text { 4B); vocabulary system built into } \\
\text { Proloquo2Go; video modeling } \\
\text { (VM); self-modeling video } \\
\text { (VSM); Robust-Improvement } \\
\text { Rate Difference (R-IRD). }\end{array}$ & $\begin{array}{l}\text { Intervention based on the use of } \\
\text { videos. }\end{array}$ & $\begin{array}{l}\text { It was found that the } \\
\text { incorporation of video-based } \\
\text { modeling can culminate in the } \\
\text { promotion of skills involving } \\
\text { conversation in individuals with } \\
\text { Autistic Spectrum Disorder } \\
\text { (ASD), stimulating social } \\
\text { interaction. }\end{array}$ \\
\hline Caron, et al., 2018 & $\begin{array}{l}\text { Child Autism Rating Scale } 2 \\
\text { edition (CARS-2); Language } \\
\text { Listening Comprehension Test } \\
\text { (TACL-3); Dolch word } \\
\text { inventory; Woodcock Reading } \\
\text { Domain Test-3 (WRMT-III) }\end{array}$ & $\begin{array}{l}\text { Introduction of applications with } \\
\text { software resources for the transition } \\
\text { to literacy (TCL2) aiming at the } \\
\text { development and dynamic reading } \\
\text { of words. }\end{array}$ & $\begin{array}{l}\text { Improved communication, } \\
\text { learning, and literacy process. }\end{array}$ \\
\hline Mandak et al., 2019 & $\begin{array}{l}\text { T2L resource; Peabody Image } \\
\text { Vocabulary Test } 3 \text { Edition } \\
\text { (PPVT-III) }\end{array}$ & $\begin{array}{l}\text { Development of activities using } \\
\text { applications and dynamic text for } \\
\text { word identification. }\end{array}$ & $\begin{array}{l}\text { Improvements during the reading } \\
\text { process, enabling word } \\
\text { recognition. }\end{array}$ \\
\hline Westeryeld et al., 2017 & $\begin{array}{l}\text { Social Communication } \\
\text { Questionnaire (SCQ); Vineland } \\
\text { Adaptive Behavior Scale-II } \\
\text { (VABS-II); Mullen Early } \\
\text { Learning Scales (MSEL); Picture } \\
\text { Vocabulary Test (PPVT-4) } \\
\text { Peabody-4; Quality of Oral } \\
\text { Narrative (ONQ); Knowledge of } \\
\text { the name and sound of the letter } \\
\text { LNK; Phonological awareness; } \\
\text { PWA printing; Interview with the } \\
\text { main caregiver }\end{array}$ & $\begin{array}{l}\text { Use of recordings and images for } \\
\text { intervention aimed at the reading } \\
\text { process during literacy through } \\
\text { verbal and non-verbal skills. }\end{array}$ & $\begin{array}{l}\text { The presented research looked at } \\
\text { some aspects of development } \\
\text { during the preschool period, such } \\
\text { as literacy skills, cognitive and } \\
\text { language skills. In this sense, it } \\
\text { was found that children with } \\
\text { Autistic Spectrum Disorder } \\
\text { presented an adequate } \\
\text { development in the interpretation } \\
\text { of the code, although they had } \\
\text { difficulty in the literacy skill } \\
\text { related to meaning, which can }\end{array}$ \\
\hline
\end{tabular}




\begin{tabular}{|c|c|c|c|}
\hline & & & $\begin{array}{l}\text { help in the survey of early } \\
\text { intervention to help in the literacy } \\
\text { period. }\end{array}$ \\
\hline Sam et al, 2020 & $\begin{array}{l}\text { Autism Program Environment } \\
\text { Assessment Rating Scale- } \\
\text { preschool elementary version } \\
\text { (APERS-PE); observation of the } \\
\text { school location; interview with } \\
\text { school officials and family } \\
\text { members }\end{array}$ & $\begin{array}{l}\text { Intervention based on the insertion } \\
\text { of a program model created by the } \\
\text { National Center for Professional } \\
\text { Development (NPDC) and its } \\
\text { comparison with Services as Usual } \\
\text { Condition (SAU) }\end{array}$ & $\begin{array}{l}\text { It was found that the insertion of } \\
\text { the model originated from the } \\
\text { National Center for Professional } \\
\text { Development (NPDC) had more } \\
\text { satisfactory results compared to } \\
\text { the SAU (Service as Usual } \\
\text { Condition) model, considering } \\
\text { that it had a positive evolution } \\
\text { regarding the learning goals of the } \\
\text { autistic student }\end{array}$ \\
\hline Locke et al, 2016 & $\begin{array}{l}\text { Assessment through POPE: } \\
\text { Observation of peer involvement } \\
\text { in the playground; ADOS: } \\
\text { Autism Diagnosis Observation } \\
\text { Schedule; Application of DP } \\
\text { (Standard Deviation) }\end{array}$ & $\begin{array}{l}\text { The behavior of children with } \\
\text { Autistic Spectrum Disorder during } \\
\text { the recess period was evaluated } \\
\text { using a timed interval behavior } \\
\text { coding system in an inclusive school } \\
\text { setting. }\end{array}$ & $\begin{array}{l}\text { There was an improvement in } \\
\text { social engagement, social } \\
\text { interactions in total, success in } \\
\text { starting them, and opportunities to } \\
\text { respond to a social approach from } \\
\text { a classmate. }\end{array}$ \\
\hline Fantasia et al, 2020 & $\begin{array}{l}\text { Application of ADOS: } \\
\text { Observation Schedule for } \\
\text { Diagnosis of Autism; Peabody- } \\
\text { Revised Image Vocabulary Test } \\
\text { (PPVT-R); Vineland Adaptive } \\
\text { Behavior Scale-II (VABS-II); }\end{array}$ & $\begin{array}{l}\text { Use of memory game via tablet, } \\
\text { aiming to identify whether episodic } \\
\text { memory is stimulated when there is } \\
\text { active control of learning, as it } \\
\text { occurs in other children and adults. }\end{array}$ & $\begin{array}{l}\text { It was observed better recognition } \\
\text { of active objects than inactive } \\
\text { ones, that is, they were more } \\
\text { accurate in recognizing objects } \\
\text { that she can choose how to study } \\
\text { them. }\end{array}$ \\
\hline Plavinick et al, 2015 & $\begin{array}{l}\text { Rating Scale - 2nd Edition } \\
\text { (CARS-2); Diagnosis and } \\
\text { Statistical Manual of Mental } \\
\text { Disorders (DSM-IV); GARS-2: } \\
\text { Gilliam Autism Rating Scale- } \\
\text { Second Edition; video clips }\end{array}$ & $\begin{array}{l}\text { Insertion of video modeling to } \\
\text { encourage learning and social } \\
\text { interaction }\end{array}$ & $\begin{array}{l}\text { It was found that the insertion of } \\
\text { video modeling can be effective } \\
\text { in stimulating social interaction } \\
\text { and can be used by professionals } \\
\text { for the learning process in } \\
\text { children with autism. }\end{array}$ \\
\hline Dass et al, 2018 & $\begin{array}{l}\text { Inset of the GARS-3: Gilliam } \\
\text { Autism Rating Scale-Third } \\
\text { Edition; EVT-2: Expressive } \\
\text { Vocabulary Test - Second } \\
\text { Edition; PPVT-4: Peabody- } \\
\text { Fourth Edition Picture } \\
\text { Vocabulary Test; VB-MAPP: } \\
\text { Assessment of verbal behavior } \\
\text { milestones and placement } \\
\text { program. }\end{array}$ & $\begin{array}{l}\text { Use of the DTI (Discreet } \\
\text { Experimental Instruction) method } \\
\text { modified for smell, with a total of } \\
20 \text { odor stimuli unknown by the } \\
\text { participants, with } 4 \text { olfactory } \\
\text { categories and } 16 \text { olfactory items, to } \\
\text { ASDch them to discern the } \\
\text { characteristics of each item and } \\
\text { category. }\end{array}$ & $\begin{array}{l}\text { It was concluded that the DTI } \\
\text { (Discreet Experimental } \\
\text { Instruction) method also works to } \\
\text { ASDch the recognition of } \\
\text { olfactory stimuli to children with } \\
\text { autism when they have a well- } \\
\text { established repertoire of visual } \\
\text { stimuli. Furthermore, it was seen } \\
\text { that such children were able to } \\
\text { classify olfactory stimuli when } \\
\text { instructed to define secondary } \\
\text { olfactory stimuli. }\end{array}$ \\
\hline Yun et al, 2017 & $\begin{array}{l}\text { Autism diagnostic observation } \\
\text { schedule (ADOS); application of } \\
\text { communication, social } \\
\text { responsiveness, and infant } \\
\text { behavior questionnaires for those } \\
\text { responsible for the child; } \\
\text { assessment of the frequency of } \\
\text { eye contact the child made and its } \\
\text { accuracy in recognizing a facial } \\
\text { expression. }\end{array}$ & $\begin{array}{l}\text { Interaction between an autistic child } \\
\text { and a humanoid robot, with the help } \\
\text { of an observational therapist. The } \\
\text { objective was to promote the } \\
\text { development of eye contact and } \\
\text { recognition of facial expressions by } \\
\text { the child. }\end{array}$ & $\begin{array}{l}\text { Robots were found to be as } \\
\text { effective in stimulating the child's } \\
\text { development in eye contact and } \\
\text { facial recognition as human } \\
\text { therapists, in addition to } \\
\text { stimulating interest in the tests } \\
\text { more than the therapists were } \\
\text { able. }\end{array}$ \\
\hline $\begin{array}{l}\text { Kostrubieck and Kruck, } \\
2020\end{array}$ & $\begin{array}{l}\text { Application of the verbal } \\
\text { cognition subtest; Social } \\
\text { Communication Questionnaire } \\
\text { (SCQ); PEP: Psychoeducational } \\
\text { Profile; SPCR: Sensory Profile } \\
\text { Checklist }\end{array}$ & $\begin{array}{l}\text { Application of an educational } \\
\text { method based on the use of robotic } \\
\text { interventions aimed at the } \\
\text { development of social skills }\end{array}$ & $\begin{array}{l}\text { It was found that the robot reward } \\
\text { system was more accepted by } \\
\text { children. The robot can reduce } \\
\text { stereotyped behaviors for children } \\
\text { with a low or absent intellectual } \\
\text { deficit. }\end{array}$ \\
\hline
\end{tabular}

Source: Authors.

The comparison of greater numbers of selected studies in different countries reveal the highest number of selected studies was the United States (43.75\%), followed by France (12.5\%) and Australia (12.5\%) are presented in Table 2. Of the selected articles, the most used experimental model was the multiple-probe clinical case (18.75\%). In addition, $75 \%$ of the 
articles had a sample smaller than 30 participants. Still, about these data, the youngest and oldest age groups in the sample were, respectively, 4 and 18 years old, with an average of 11 years old. Most articles, 75\%, did not clearly (and sometimes completely) show the duration of the intervention.

Table 3 shows that there was not a single predominant assessment tool used by the authors (the majority used more than one type of assessment). The most used assessment tools were: CARS, CARS-2, VABS-II, VB-MAPP, and PPVT-IV (12.5\%). Intervention methods also varied a lot between articles, 31.25\% of them used games and games with children, 37.5\% used new ASD teaching methods not related to games, and 56.25\% adhered to the use of technologies (robots, software, videos, applications, electronic games, and recordings). It is also worth mentioning that $100 \%$ of the articles determined or confirmed a method capable of developing the socio-cognitive and/or learning skills of infants with ASD. Therefore, educational interventions were focused on children and adolescents between 2 and 18 months with autism spectrum disorder (ASD) results were satisfactory, stimuli social life and knowledge process.

\section{Discussion}

The purpose of this study was to select and analyze the main methods of educational intervention involving children and adolescents ( 2 to 18 years old) with autism. Of the studies evaluated, ten of them evaluated people between 4 and 10 years old. Early childhood (zero to 6 years) is a period of development marked by greater brain plasticity (Carson et al., 2017), so it is a time when affective bonds with family members (mainly), development, and learning are more obvious. Such experiences can further affect physical, cognitive, emotional, and social development (Leahy Warren, 2005). During early childhood, it is possible to diagnose autism at an average age of 2 years. The main damages are social and communication. Therefore, the treatment initiated in primary infants could contribute to cognitive, social, and linguistic development (Stone and Tunner, 2005)

Second childhood (6 to 10 years old) is one of the stages of child development with the greatest conflict between children and parents and/or guardians, including school educators themselves. In this sense, affection pedagogy is one of the methodologies adopted by educational institutions to assist in the formation of students' emotional intelligence (Silva and Santos, 2020). Thirumanickam, et al. (2018) evaluated adolescents with autism between 11 and 18 years old. During adolescence/puberty, 10 to 18 years of age, affection conflict is still imminent, and socio-emotional maturation marks the end of this cycle (Burnett et al., 2011). Considering the autistic student, the optimization of learning with playful or technological interventions is proven to be efficient to ensure the cognitive and social development of these children and adolescents (Westeryeld et al., 2017; Sam et al, 2020; Locke et al, 2016; Fantasia et al, 2020).

One of the limitations was that nine studies used a sample of less than 10 people and the most of the studies evaluated $(\mathrm{N}=14)$ in this systematic review were carried out in countries with a high index of social and economic development. Thus, the results obtained by the studies may not reflect (be comparable) in societies in less developed regions such as Latin America and Africa, since, in these countries, the pedagogical resources for the inclusion of students with disabilities in an educational environment may be scarcer. However, it is noteworthy that, in the case of Brazil, several important changes have taken place since the 70s concerning the inclusion of students with special educational needs in regular schools (Rahme, 2013). Since then, ASD teachers have been trained and have developed different methodologies and educational strategies that address the special education audience.

When evaluating the duration of interventions, only four studies provided the exact time. The studies by Leão, et al (2019); Saint-Georges, et al (2020); Sam, et al (2020); Kostrubiek and Kruck (2020) lasted at least five months, demonstrating that this time can be used to verify significant changes in the behavior and development of the evaluated population.

The analysis of the results of the selected articles showed the use of different methods to promote development (Table 
3). The use of such methods obtained satisfactory results. All authors concluded that through their respective applied interventions it was possible to achieve success in the development of children and adolescents with autism.

Some of the methods used in the studies explored various aspects related to vision, hearing, smell, language, and sociability to reach a higher level of psychological, social, and cognitive development. Visual and audiovisual stimuli can produce communication in mute children, directing behavior (Cardoso et al., 2021; Orrú, 2011).

Leão et al (2019) showed that the intervention anchored in the self-regulation of learning in the context of Specialized Educational Service (AEE), considering the context and in the classroom, contributed to improving the communication of three autistic children (10 to 12 years old). The results favored the increase in the frequency of non-verbal initiatives and the use of eye contact in responses to communication partners in the AEE.

In addition, it was evidenced that the use of interactive technological devices (applications, virtual games, video modeling, and robots) stimulated the cognitive and social development of the evaluated population (Plavinick, et al, 2015; Yun, et al, 2017; Leão, et al., 2019; Fantasia, et al, 2020; Kostrubieck and Kruck, 2020; Saint-Georges, et al., 2020).

The use of technological resources has become increasingly frequent in education (Silva, 2016). Technologies collaborate for the application of olfactive ASD teaching methodologies, in which the child and adolescent participate in the entire process, being able to develop cognitive, sensory, and interactional capacities. Most technological resources provide visual stimulation, and this feature is what makes it attractive for students with autism. In this sense, educators using these resources can expand and provide learning, cognitive and social-emotional development of autistic students. In addition, the results of the evaluated studies showed that learning in the classroom through the use of computers, virtual games, among others, were applied in the family and daily environment of the population evaluated with autism, improving social interaction and the quality of Your lives.

Fantasia et al (2020) assessed the potential of active control to improve learning in children aged 6 to 12 years diagnosed with an autism spectrum disorder. Participants were presented with a memory game available on a touchscreen tablet, in which children were asked to remember as much as possible of the objects presented. For half of the objects, children could decide the order and pace of the study (active condition); for the other half, they passively observed the study decisions of a previous participant (yoke condition). The results showed that recognition memory was more accurate when children could actively control the order, pace, and frequency of the study experience.

Thirumanickam, et al. (2018) evaluated four adolescents with autism between 11 and 18 years old. The study compared the effectiveness of packaged video modelling and video self-modelling interventions to develop conversational behaviors. Although the sample number was small, the results demonstrated that, overall, video-based modelling used in conjunction with a system of least prompts was effective in promoting conversation skills in adolescents with autism. Therefore, the development and use of new/innovative educational methods for the development of children and adolescents with autism is fundamental to the educational and social inclusion of this population.

\section{Conclusion}

Based on the choice and papers reviews, an improvement in the socio-cognitive development of children and adolescents were observed. In this sense, several educational techniques and equipment were used to promote this result, from playful games to the use of humanoid robots, culminating in the reduction of social and educational barriers often caused by autism spectrum disorder. One of the limitations was that the studies used a small sample number and the most then were performed in countries with a highest index of social and economic development, therefore, the results obtained may not be comparable in societies with lowest index of economic development. Thus, these results allowed us to conclude that: 1) it is possible to stimulate the cognitive development in children and adolescents with autism (2 to 18 years old) using several 
educational techniques and technologies, enabling a healthier social interaction and greater ease of learning; 2) there is scarcity of studies assessing the effectiveness of educational interventions to improve cognitive and social ability of children and adolescents with autism in countries with lowest index of economic development.

\section{Acknowledgments}

The authors acknowledge the infrastructure and support of the Universidade José do Rosário Vellano (UNIFENAS). This study was financed in part by the Coordenação de Aperfeiçoamento de Pessoal de Nível Superior - Brazil (CAPES) Finance Code 001 and the National Council for Scientific and Technological Development - Brazil (CNPq).

\section{References}

Arias, V. B., Gómez, L. E., Morán, M. L., Alcedo, M. Á., Monsalve, A., \& Fontanil, Y. (2018). Does Quality of Life Differ for Children With Autism Spectrum Disorder and Intellectual Disability Compared to Peers Without Autism? Journal of autism and developmental disorders, 48(1), $123-136$.

Associação Brasileira de Psiquiatria. [https://www.abp.org.br/].

Association, A. P. Diagnostic and statistical manual of mental disorders - 4th edn, text revision. Washington, 2000. DC: American Psychiatric Association.

Biggs, E. E., \& Carter, E. W. (2016). Quality of Life for Transition-Age Youth with Autism or Intellectual Disability. Journal of autism and developmental disorders, 46(1), 190-204.

Buemo, B., Alli, F., Iracet, J. V., Ribas, L., Perreira, R., Kruel, C. S., Guazina, F. M. N., Carlesso, J. P. P. (2019). Autismo no Contexto Escolar:A Importância da Inserção Social. Research, Society And Development, 8(3):e2783822.

Burnett, S., Thompson, S., Bird, G., \& Blakemore, S. J. (2011). Pubertal development of the understanding of social emotions: Implications for education. Learning and individual differences, 21(6), 681-689.

Carson, V., Lee, E.-Y., Hewitt, L., Jennings, C., Hunter, S., Kuzik, N., ... \& Tremblay, M.S. (2017). Systematic review of the relationships between physical activity and health indicators in the early years (0-4 years). BMC Public Health, 17(Suppl 5), 854.

Caron, J., Light, J., Holyfield, C., \& McNaughton, D. (2018). Effects of dynamic text in an AAC app on sight word reading for individuals with autism spectrum disorder. Augmentative and alternative communication (Baltimore, Md.: 1985), 34(2), 143-154.

Da Silva, G. F., Santos, M. M. F. (2020). A importância da afetividade no processo de aprendizagem na educação infantil. Brazilian Journal of Development (Curitiba), 6(1), 1029-1047.

Dass, T. K., Kisamore, A. N., Vladescu, J. C., Reeve, K. F., Reeve, S. A., \& Taylor-Santa, C. (2018). Teaching children with autism spectrum disorder to tact olfactory stimuli. Journal of applied behavior analysis, 51(3), 538-552.

Dos Santos, G., Goldbaum, M., César, C., \& Gianini, R. J. (2020). Care seeking behavior of people with common mental disorders in São Paulo-Brazil. International journal of mental health systems, 14,36 .

Dueñas, A. D., Plavnick, J. B., \& Bak, M. (2019). Effects of Joint Video Modeling on Unscripted Play Behavior of Children with Autism Spectrum Disorder. Journal of autism and developmental disorders, 49(1), 236-247.

Eshraghi, A. A., Liu, G., Kay, S. S., Eshraghi, R. S., Mittal, J., Moshiree, B., \& Mittal, R. (2018). Epigenetics and Autism Spectrum Disorder: Is There a Correlation?. Frontiers in cellular neuroscience, $12,78$.

Fantasia, V., Markant, D. B., Valeri, G., Perri, N., \& Ruggeri, A. (2020). Memory enhancements from active control of learning in children with autism spectrum disorder. Autism: the international journal of research and practice, 24(8), 1995-2007.

Frye, R. E., Vassall, S., Kaur, G., Lewis, C., Karim, M., \& Rossignol, D. (2019). Emerging biomarkers in autism spectrum disorder: a systematic review. Annals of translational medicine, $7(23), 792$.

Jadilson Marinho da Silva, J. M. (2016). Novas tecnologias em sala de aula. Revista ciencia, salud, educación y economia, 10.

Jury, M., Perrin, A. L., Desimbre, C., Rohmerc, O. (2021). Teachers' attitudes toward the inclusion of students with autism spectrum disorder: Impact of students' difficulties. Research in Autism Spectrum Disorders, 83:e.101746.

Kostrubiec, V., \& Kruck, J. (2020). Collaborative Research Project: Developing and Testing a Robot-Assisted Intervention for Children With Autism. Frontiers in robotics and $A I, 7,37$.

Kuhlthau, K., Orlich, F., Hall, T. A., Sikora, D., Kovacs, E. A., Delahaye, J., \& Clemons, T. E. (2010). Health-Related Quality of Life in children with autism spectrum disorders: results from the autism treatment network. Journal of autism and developmental disorders, 40(6), 721-729.]

Leahy Warren, P. (2005), First-time mothers: social support and confidence in infant care. Journal of Advanced Nursing, 50: 479-488. 
Leão, A.T., Camargo, S. P. H., Frison, L. M. B. (2019). Communication of students with ASD: A self-regulation of learning based intervention. Psicologia: teoria e prática, 21(3):473-500.

Lee, G. T., Qu, K., Hu, X., Jin, N., \& Huang, J. (2020). Arranging play activities with missing items to increase object-substitution symbolic play in children with autism spectrum disorder. Disability and rehabilitation, 1-13. Advance online publication.

Locke, J., Shih, W., Kretzmann, M., \& Kasari, C. (2016). Examining playground engagement between elementary school children with and without autism spectrum disorder. Autism: the international journal of research and practice, 20(6), 653-662.

Mandak, K., Light, J., \& McNaughton, D. (2019). Digital Books with Dynamic Text and Speech Output: Effects on Sight Word Reading for Preschoolers with Autism Spectrum Disorder. Journal of autism and developmental disorders, 49(3), 1193-1204.

Monteiro, M. A., Santos, A. A. A., Gomes, L. M. M., Rito, R. V. V. F. (2020). Autism spectrum disorder: a systematic review about nutritional interventions. Revista Paulista de Pediatria [online], 38:e.2018262.

Page, M. J., McKenzie, J. E., Bossuyt, P. M., Boutron, I., Hoffmann, T. C., Mulrow, C. D, et al. (2021). The PRISMA statement: an updated guideline for reporting systematic reviews. $B M J, 372: 71$.

Saint-Georges, C., Pagnier, M., Ghattassi, Z., Hubert-Barthelemy, A., Tanet, A., Clément, M. N., Soumille, F., Crespin, G. C., Pellerin, H., Cohen, D., \& GPIS study group (2020). A developmental and sequenced one-to-one educational intervention (DS1-EI) for autism spectrum disorder and intellectual disability: A three-year randomized, single-blind controlled trial. EClinicalMedicine, 26, 100537.

Sam, A. M., Odom, S. L., Tomaszewski, B., Perkins, Y., \& Cox, A. W. (2021). Employing Evidence-Based Practices for Children with Autism in Elementary Schools. Journal of autism and developmental disorders, 51(7), 2308-2323.

Sengupta, K., Lobo, L., \& Krishnamurthy, V. (2017). Educational and Behavioral Interventions in Management of Autism Spectrum Disorder. Indian journal of pediatrics, 84(1), 61-67.

Stone, B. G., Mills, K. A., Saggers, B. (2018). Online multiplayer games for the social interactions of children with autism spectrum disorder: a resource for inclusive education. International Journal of inclusive education, 23(2):209-228.

Stone, W. L., Turner, L. (2005). The Impact of Autism on Child Development. Encyclopedia on early childhood Development, 1-5.

Thirumanickam, A., Raghavendra, P., McMillan, J. M., \& van Steenbrugge, W. (2018). Effectiveness of video-based modelling to facilitate conversational turn taking of adolescents with autism spectrum disorder who use AAC. Augmentative and alternative communication (Baltimore, Md.: 1985), 34(4), 311322 .

Westerveld, M. F., Paynter, J., Trembath, D., Webster, A. A., Hodge, A. M., \& Roberts, J. (2017). The Emergent Literacy Skills of Preschool Children with Autism Spectrum Disorder. Journal of autism and developmental disorders, 47(2), 424-438.

Yun, S. S., Choi, J., Park, S. K., Bong, G. Y., \& Yoo, H. (2017). Social skills training for children with autism spectrum di sorder using a robotic behavioral intervention system. Autism research: official journal of the International Society for Autism 